\title{
CUTTING COMMENTARY: CELESTINA, SPECTACULAR DISCOURSE, AND THE TREACHEROUS GLOSS
}

\author{
Linde M. Brocato \\ University of Illinois-Urbana
}

In a suggestive and still fundamental analysis of the deletions and interpolations of the Tragicomedia, Stephen Gilman changes the focus from the authorship of the various editions and parts of Celestina to stylistic and conceptual aspects of the work. As he brings his own stylistic analysis to bear on the structural and philosophical unity of the text, he asserts that the language of Celestina is "spoken" but not necessarily "popular" in its "inner intentionality,"

written as if emerging from one life towards another. Each word (...) is supported by and gives access to both a yo and a tú. Dialogue is for Rojas the language which results from the meeting of two lives. (Gilman, Art 19)

Although in The Art of $L a$ Celestina Gilman recognizes an important aspect of Celestina, this dyadic and unified approach closes off analysis of the ways that the text itself is a spectacle of performance and textuality, beyond dialogue, dyads, and "lives" - a fact implicit in Gilman's own analysis of the places where an original text is supplemented and sutured.

In fact, Celestina is primarily a series of overheard dyadic dialogues, often intertwined with each other or with commentary, in which characters stage their own discourses for the benefit of spectators within (or outside) the text, and, as spectators themselves, monitor each others' discursive performances. Gilman's assertion that "Rojas insists that each speech (...) exist in function of speaker and listener and not 
merely for the instruction or entertainment of the reader" (Art 19) downplays this important dimension of dialogue in the work as spectacle and as pastiche. Often, discourse is staged as performance for the benefit of a third party, whether it be other characters or us as readers. ${ }^{1}$ Indeed, a third party is almost always watching and listening, reacting critically. More than the existentialist encounters of "a yo and a tü," Celestina explodes the dyadic communication of characters in a continual series of a yo versus a tu , all staged and observed from the margins of dialogue. ${ }^{2}$

In addition to this interpenetration of the characters' interchanges, textual asides point to the intertextuality of their exchanges, also permeated by texts. These (pre)texts of ten provide both content and form for interaction, as well as the criteria deployed (often in asides) for evaluating the 'text' being elaborated. That is, the patching and grafting of already existing texts and discourses (e.g., Boethius and Petrarch; Corbacho and Laberinto de Fortuna; consolation, misogyny, and courtly love) is also explicitly commented on within the text by interlocutors and spectators. ${ }^{3}$ For example, in auto II, Sempronio counters Calisto's refusal to cheer himself based on his own reading of "quantos scrivieron consuelos" with an equally text-based reply: "Lee más adelante. Buelve la hoja" (II.11-.12, Severin 132-133). In Celestina, then, we find speakers, listeners, and readers discursively positioned as critical spectators in the competition of appetites, desires, and wills played out in language. As such, they are made to speak as readers from the margins of dialogue (in

${ }^{1}$ In addition to the asides, the monologues also undermine any absolute applicability of Gilman's assertion, since they serve to let the reader/listener in on the inner processing attributed to the character, not furthering action, but revealing the interior discourse - character, emotions, motives, self-delusion, rationalization - of the characters. For an analysis of the asides in Celestina, see Lida de Malkiel, ch. 5, "Los apartes," 136-148; Patricia Finch, "The Uses of the Aside in Celestina;" and Chantal Cassan Moudoud, "El Uso de los apartes en Celestina." Lida's analysis is fundamentally mimetic, i.e. how does the work realistically reflect 'life,' and literary, i.e. how does the work fit in the Western (classical) tradition.

${ }^{2}$ I wish to thank Catherine Brown for her particularly felicitous articulation of this contrast.

${ }^{3}$ Severin's edition of Celestina annotates much of this, and references to studies of sources can be found in her bibliography. 
their asides) at strategic moments in the text, exposing the rhetorical self-representation and the fictions of others. ${ }^{4}$

\section{Juntar con la virtud de la lengua (X.11): Asides and the text}

In the first extant edition of Celestina (Burgos 1499), the asides are not editorially indicated; they are only so signalled from the edition of "Sevilla 1502" onward (Lida 136-137, n1). The recognition that these utterances within the text are different does imply a working concept of aside, however implicit, and, as a consequence, produces a need or desire to signal (and clarify) the complex workings of the text. ${ }^{5}$ Most general or literary definitions of 'aside' make only the broadest of distinctions, as in this one from the Diccionario de la Real Academia, and often do not evaluate function or significance within the text:

Lo que en la representación escénica dice cualquiera de los personajes de la obra representada, como hablando para sí o con aquel o aquellos a quienes se dirige y suponiendo que no lo oyen los demás. (DLE 107c)

Lida de Malkiel, in her La Originalidad artistica de 'La Celestina', develops a taxonomy of the aside, and articles by Finch and Moudoud discuss the

- All references and quotations are taken from the critical edition of Miguel Marciales prepared by Brian Dutton and Joseph Snow, Celestina. Tragicomedia de Calisto y Melibea (Urbana and Chicago: U Illinois P, 1985), and will be cited in the text with the auto and versiculo as indicated in Marciales' convenient division of the text, along with the page number from Severin's Cátedra edition for the convenience of readers not working with Marciales' (often problematic) edition.

${ }^{5}$ Asides are textually quite unstable, often depending on the editor's judgment in marking them. This paper is based on the mapping of asides in Marciales' edition; Severin does not always follow the same mapping, and often separates compound focus by spaces between the dialogues rather than signalling an aside. In one instance for example (auto XIV), she separates two 'scenes' and, rather than marking Melibea's speech an aside as does Marciales, marks Sosia's by placing it in parentheses (XIV.17-.18, Severin 286). In fact, there are often cues in the text itself, e.g. in Burgos 1499 (facs. Hispanic Society of America, 1909, repr. 1970), Act IX begins with Sempronio and Pármeno arriving at Celestina's house. Their discussion, signalled as an aside in later editions and in critical editions, is discursively introduced by Pármeno's comment "calla que esta abierta su puerta" $(\mathrm{H} 1 \mathrm{r})$. Often, however, in that edition, asides would simply require sufficient reading/discursive competence to make sense of the series of interchanges. 
asides in Celestina, using a basic notion of the phenomenon. ${ }^{6}$ Expanding somewhat the taxonomies of both the Diccionario and of Lida's chapter, the asides can be provisionally classified in Celestina. For example, "hablando para si" is signalled twice as an aside in apparently non-dialogic (and presumably interior) moments in the midst of an ongoing conversation (III.4-5, Severin 140 - Sempronio in conversation with Celestina; XII.4-5, Severin 256 - Calisto in conversation with Sosia and Tristán).

Many of the asides in Celestina directed to others and "suponiendo que no lo oyen los demás" function as moments of compound place or focus within a single scene of the text (Lida 141). That is, what editors have signalled as asides can be distinct or interlaced conversations in the same or in adjunct spaces: compare scenes of Elicia with Crito at Celestina's house upon Sempronio's arrival at the door (I.73, Severin 104) or Sempronio and Celestina outside Calisto's door as they arrive for their first interview with him (I.114 ff., Severin $114 \mathrm{ff}$.). ${ }^{7}$

Yet the supposition that "los demás" do not hear asides does not in fact hold in Celestina as Lida de Malkiel notes (137), and the question may well be which others are not supposed to hear or what it means that they and we do hear. Many of the asides 'supposedly not heard by the rest' (DLE $107 \mathrm{c}$; translation mine) as well as those that signal occupation of the same scenic space but split the focus are indeed overheard, and consist of commentary by one interlocutor of a dialogue who has

${ }^{6}$ Lida de Malkiel discusses the use of asides to advance the plot (dramatic function) and to deepen characterization (novelistic function) (Lida 143); Moudoud follows her in demonstrating a "dynamic" function for the asides, supplementing also the comic and didactic functions signalled by Bataillon and Severin, and contesting Finch's assertion that the asides do not "[function] to advance the plot" (Finch 19, cited in Moudoud 13, who also cites Bataillon and Severin). Moudoud, however, uses the asides as evidence of a previous author for auto I, and makes a generic distinction on the basis of their distribution (summed up at 19). My taxonomy does not follow those of the above mentioned scholars exactly, although it shares some basic classifications and observations with their analyses, especially Lida de Malkiel (136-139).

7 These asides largely signal a spatial distinction (upstairs/downstairs; inside/outside), although even these distinctions are not without other implications. In addition, voices at a distance are also represented twice (XIV.17-18, Severin 286; XVI.19-20, Severin 305-306). 
suddenly become a critic of the other." Some are dialogues parallel to primary dialogues in which non-interlocutors in the one are hearing witnesses of the other. In both cases the asides often penetrate the principal dialogue. That is, they are almost always overheard within the text, and almost always comment on the foregrounded dialogue.' In this interplay of dialogue and eavesdropping, Celestina reveals a world of continuous discourse and discursive sensitivity (Read 95; Gaylord 7). Rather than "half-heard mumblings which the author makes use of for comic effect and to reveal the thoughts of the secondary characters" (Simpson $x$ ), asides are critical to the text and its world, and to our understanding of it.

${ }^{8}$ An inventory of the scenes in which an apartc is overheard includes: $1.24, .27$, $.40, .58-9, .62, .122, .123$ (and an allusion to overhearing at I.125); II.15-.16, .18; IV.27, .43-.44, $61-.62, .67, .86, .88-.90$ (i.e. all the asides in Celestina's first interview with Melibea); V.12; VI.2-3, .23-.24, .37, .41-.42; VII.33, .93; VIII.46; IX.71; $X .8-9, .25$. From the death of Celestina, the asides lose the aspect of interpenetration that characterizes them from I through $X$, whether in interaction with Celestina or not. This is also noted by Moudoud (19-20).

The only scenes in which conversation is not largely focussed between only two interlocutors seem to be those scenes in the underworld inhabited by Celestina, Elicia, and Areusa: Sempronio's arrival at Celestina's house in I; Celestina's 'last supper' in IX, which breaks down into erotic horseplay after the story (staged for Lucrecia's benefit) of Celestina's 'golden age.' Lucrecia's role as sidelines listener is also indicated by her banishment from the scene twice in the work, once by Celestina (X.26, Severin 242), and once by Calisto (XIV. 14, Severin 285); in addition, it is she who fills in the rest of Melibea's story for Pleberio (XXI.4, Severin 336).

${ }^{9}$ It is in sociolinguistic discourse analysis that one finds this quality of the aside analyzed and theorized; cf. Barbara Strodt-Lopez, "Tying it all in: Asides in university lectures," in which she analyzes the function of asides in professors' lectures as a "running commentary" (136) which are in fact deeply relevant to the global frame of the lecture. "The contribution of asides, the most blatant form of local disjunction, to global semantic coherence suggests that global coherence derives from integration of multiple, diverse semantically-based discourse structures rather than dominance of one" (135). Since Celestina is not a university lecture nor a 'real' sample of contemporary discourse, one cannot in good conscience simply apply this analysis anachronistically. Nonetheless, these findings regarding contemporary university discourse and the nature of asides resonate with the function of the asides in a text written by a late fifteenth century university student in a way that is striking if not compelling. They corroborate as well the notion that the asides, in addition to dramatizing the theme of discourse itself, point to what is in fact deeply significant in the text although not necessarily in terms of their content. Further, 1 do not wish to signal any mimesis of 'life' but rather the function and potential of text and language. 
The world of Celestina, then, rather than an existential one or even a Bakhtinian world of characters, expressing and completing themselves and each other in utopic dialogue, is a world of rhetorical fictions. It is a murmuring and critical world, one in which what is said by those who occupy discursive space is constantly subverted by those who, for any number of reasons, may not or do not choose to speak openly in the immediate context. ${ }^{10}$ It is also a world of fictions in which all dialogue is continually monitored. In the world of Celestina, all discourse (and therefore being) is vulnerable and public. This vulnerability is explicitly signalled by the asides scattered throughout the text. Indeed, it is narrated by Rojas in the prologue's tale of the scene of reading, as its readers contend with and emend the Comedia (P.19-.27, Severin 81 ).

The Prologue has long served to fuel biographical speculation; the asides have been analyzed in terms of their dramatic or novelistic functions. There is, however, another important dimension of Celestina: the ways in which it is a literate, even bookish, text about discourse, a dialogic one in both the obvious and the Bakhtinian senses - "spoken" but not "popular."11 That is, the asides in Celestina focus attention on discursive multiplicity and fragmentation; at the same time, they also call attention to Celestina's discourse as fiction (made) and as text (woven). Its textuality is complicated both by multiple expansions and revisions of the text, but also by integrating many other texts and discourses. The asides serve more than the commonsensical and mimetic "modo convencional de expresar dentro del cauce único de la obra de teatro los muchos cauces simultáneos por los que en la realidad fluyen el pensamiento y la palabra" (Lida 136) or the underlining of any seductive "verosimilitud" of the dialogue (Moudoud 16). Rather, if we take

${ }^{10}$ Note that this includes, largely, Calisto and Pleberio; the others including Melibea and Celestina have to make such space by hook or by crook at times. There is a very nuanced interplay of power, position, and discursive space, all of which are distinct from the rhetorical techniques of persuasion and coercion at play in the dialogues. Note also that Gilman comments on Celestina's "murmuring" on 22. Lida de Malkiel notes that "con la sola excepción del débil Calisto (...) el aparte está exclusivamente en boca de la gente baja" (139), coding this "curiosa peculiaridad" as yet more verosimilitude in the realistic representation of class antagonisms in the text. One might also reflect on Melibea's outburst on overhearing her parents discuss marriage for her.

${ }^{11}$ Mary Malcolm Gaylord extensively develops the notion that Celestina is about language and discourse in "Fair of the World, Fair of the Word: The Commerce of Language in La Cclestina" although with a different focus. 
Celestina to be about discursive and textual relations in addition to being a story of a disastrous amorous relationship, the asides become integral to an estimation of Celestina's world of words and its demise.

\section{Murmurando y susurrando contra mí en presencia (VII.2): Voices/Margins/Texts}

From beginning to end, a world of vulnerable and violated discourse is a focus - and a theme - of Celestina. In terms of focus and theme, the asides are not simply a technique serving to further action. They are action, and are fundamental to the text's "process" (P.26, Severin 81; cf. Gaylord 5-6), as writer, characters, and readers all recognize. They are a displaced focus of the text, the omnipresent sidelong glance or overheard conversation that points us to its discursiveness, its textuality. The self-conscious word deployed in conversation, then, is the materia prima of Celestina, and for the most part is overheard throughout. Celestina is therefore not as simply dyadic as Gilman suggests; rather, it takes on an added dimension due (in part) to the strategic omnipresence of the servants in scenes in which the main focus is Calisto or Melibea, and the insistent sensitivity of the latter to all discourse that surrounds them. ${ }^{12}$

Some asides that result from the permeability of walls to sound and from recognition of that fact by the characters involved are parallel dialogues in contiguous but separate spaces (cf. Moudoud 17): "como dizen, las paredes an oídos" (I.86, Severin 108) Sempronio cautions Celestina as they arrive at Calisto's house in the first auto (I.114 ff., Severin $114 \mathrm{ff}$.). In this passage, marked by editors as a series of asides in the text (e.g. in Marciales "Aparte. Afuera."), we can see a conscious performance as well as an exemplary interweaving of parallel dialogues which comment on each other. First, Celestina explicitly stages a monologue to sway Calisto: "Passos oigo. Acá decienden. Haz, Sempronio, que no los oyes. Escucha y déxame hablar lo que a ti y a mí conviene" (I.114, Severin 114). Her little drama is taken in by the credulous Calisto:

${ }^{12}$ Melibea comments on this discursive sensitivity at IV.91 in the verbal sparring around Celestina's parallel conversation with Lucrecia:

Melibea: ¿Qué le dizes, madre?

Celestina: Acá nos entendemos.

Melibea: Dímelo, que me enojo cuando yo presente se habla cosia de que no haya parte. 
Pármeno, detente. ¡Ce! Escucha que hablan estos. Veamos en qué ley vivimos $(. ..) ; \mathrm{O}$ notable muger! $(\ldots) ; \mathrm{O}$ fiel y verdadero Sempronio! ¿As visto, mi Pármeno? ¿Oíste? ¿Tengo razón? ¿Qué me dizes, rincón de mi secreto y consejo y alma mía? (I.114 and .116, Severin 114-115)

In this mirroring of one performance with another, a specular world of mutual suspicion and shadow-casting is presented to readers as well as to Calisto and Pármeno, but only the latter comments critically on the artifice in the performance (1.117-118, Severin 115). Their nature as performance is confirmed, when Parmeno's warning to Calisto is overheard by Celestina and Sempronio (I.119, Severin 115). ${ }^{13}$

Celestina is completely immersed in language as performance, as Gilman, Azar, and Gaylord have shown. Yet, as we learn, no 'sincere' discourse, or even simple dialogue, is uttered except perhaps in the reprehension and ire of, say, Pármeno (uttered as a soliloquy), or of Melibea, and of Sempronio and Pármeno as they butcher Celestina (Read $92 \mathrm{ff}.)^{14}$ Almost no discourse is invulnerable to eavesdropping and critical commentary, save the soliloquies of characters alone in their chambers or in transit through the streets "parlando (...) entre dientes" (which is often observed; see V.6, Severin 172; V.18, Severin 175). ${ }^{15}$ Rather, Celestina's verbal interchange is carefully crafted, both the surface dialogue and the asides' commentary, fine-tuned to affect actions both

${ }^{13}$ M. K. Read also finds Pármeno to be the only character who really speaks the truth until it becomes to costly to do so (92-93); I would argue that he is never entirely coopted, but does go along with the plan more gracefully after 'having' Areusa.

${ }^{14}$ Ciriaco Morón Arroyo, in "Sobre el diálogo y sus funciones literarias," states that "en La Celestina la verdad se dice siempre en los apartes; no existe en el diálogo" (280). However, I'm not entirely certain that 'truth' in terms of accurate content is the issue of the asides.

${ }^{15}$ Even closed up in his room, Calisto is overheard by Sempronio in I.13 ff.; Parmeno watches Celestina and Sempronio approach,talking and gesturing in V.18, etc. In his later soliloquies, Calisto is represented in full rhetorical mode as a series of apostrophes to the judge who had Sempronio and Parmeno summarily executed and to his own "dulce imaginacion." Here, a means of making imaginable and concrete what is not accessible via dialogue. In contrast with Lida's reading and with Lapesa's, I find Calisto here to be sophistical as well as a dreamer. 
directly and indirectly. That is to say that some of the most crucial "action" takes place on the margins, performed for an undifferentiated public as spectacle. It does not occur always as interaction between interlocutors in what is assumed to be the main focus of the scene unfolding.

It is as much to the margin that the main characters orient their performances, as much as to the center, as we witness ourselves in the interwoven commentary and performance at Calisto's door (I.114, Severin 114). Not only are all words and speech acts in the work directed to interlocutors and immediate bystanders, though; they are also played out before a larger and anonymous public. For example, Pármeno doesn't wish to give up his own potential public exemplarity even if he can 'have' Areúsa (I.160, Severin 125); Sempronio suggests that Calisto not "dar a todo el mundo qué dezir" (XI.2; Severin 249); Melibea reminds Calisto of that same public when he wants to break down the doors to her garden at their first interview (XII.40, Severin 262), and she orients herself to that public, as we will see, in auto XX.

Focus on and fear of the margins is based on the power of others' reading both words and gestures as rhetorical spectacle, reading appearance as opposed to being (or vice versa), that is, as illusion and equivocation. It is this penetrating and judging spectator at the margin that is the driving force of 'el qué dirán,' with all its potential repercussions. ${ }^{16}$ As the asides draw our attention away from the love-

16 This might figure the "qué diran" that conditions social behavior as represented in Inquisitorial, post-Expulsion Spanish literature, in which an anonymous and omnipresent audience always on the edge of discourse requires a certain appearance of conformity, and forces discursive performance toward spectacle (think of the third tratado of Lazarillo). See Gilman's The Spain of Fermando de Rojas for an imaginative recreation of late 15th century Spain; see Haim Beinart, Records of the Trials of the Spanish Inquisition in Ciudad Real. Both portray a society in which discursive (semiological) behavior is both perilous and crucial; a slip of the tongue, a jealous denunciation; a confession deemed inadequate - any of these were enough to precipitate disaster, a disaster whose workings were also discursive if altogether too real. The textual practices of the Inquisition and of the bureaucracy of the government of Spain from the Reyes Católicos through the rule of the Hapsburgs are fascinating in and of themselves, including the strict regulation of writing or transcribing confessions by the Inquisition, the scribal/notarial culture of 15 th-18th century Spain and its American possessions, the governmental practice of monitoring transactions by written means, the regulation of the kinds of literature that could be printed and could circulate in the New World. This is a study yet to be written fully, I think; 
story to the power and violence at the margin, we find there a wide range of responses in the form of critique, threat, and protest: misogynistic critique of Calisto's love for a woman and sexist disdain for Calisto's lèse virilité in his affectation and abjection (Sempronio in auto I et passim); ethical and social judgment in clichéd expression of anger, anguish, or uncertainty (Pármeno throughout); and veiled aggression that takes open discursive form in a pastiche of pseudo-philosophical discourses (Celestina throughout, but especially with Pármeno and Melibea in I, IV, VII, X). Here discursive action takes place on the edge of the narrative center, and this doubling of margin and center is also mirrored by text and discourse.

Congrua e saludable melezina - polvos de infamia, licor de corrución (X.12, .21): Double-Edged Text and Discourse

Gilman, as we have seen, sees Celestina as dialogue; Lida de Malkiel situates it in the textual tradition of mimetic humanistic comedy (Lida 29 ff.). Celestina as a text, however, is situated by Rojas not only within a textual dialogue with a friend and benefactor as invoked by the Carta, but also within a textual community of readers and critics. It is offered "no solo a vos" (el amigo) or to others similarly damaged by love, but "a cuantos lo leyeren" (C.3, .12; Severin 69, 71). In addition, the prologue invokes not only textual memory of Heraclitus and Petrarch, but a textual and discursive world rife with as much ambiguity and conflict as the natural and social worlds they describe.

This same world of text and discourse is recognized as central by the printers in their punturas, as they (and Proaza) associate the book with another textual tradition, that of classical and humanist drama, and offer it to an even wider public (Gumbrecht 195). From the "Incipit" throughout most of the "Argumentos" of each act, the printers summarize the action of each auto as largely discursive, as can be seen in the following argumentos:

compuesta en repreensión de los locos enamorados que (...) a sus amigas llaman y dizen ser su dios. Assí mismo hecho en aviso de los engaños de las alcahuetas (...). (Incipit, Severin 82)

my own work is focussed differently, and can only gesture in the direction of such an analysis. 
Entrando Calisto en una uerta (...) halló aí a Melibea (...) començole de hablar; de la qual rigorosamente despedido (...) Habló con un criado suyo llamado Sempronio, el qual, después de muchas razones (...) Entretanto que Sempronio estavn negociando con Celestina, Calisto stava razonando con otro criado suyo (...). (AI, Severin 85 )

\section{(...) queda Calisto hablando con Sempronio (...) Quedan entretanto Calisto y Pármeno juntos razonando. (AII, Severin 130)}

Mientra ellos están hablando, Pármeno, oyendo hablar Celestina, de su parte contra Sempronio, a cada razón le pone un mote, repreendiéndolo Sempronio. (AVI, Severin 176; emphasis mine throughout)

According to the arguments or rubrics, then, i.e. among at least some of its readers, the discursive also predominates within the story itself, including the asides (Parmeno's motes noted in the argumento to VI above), which are seen as integral in at least one moment of the text (the argument to VI, cited above).

Significantly, it is in fact a discursive performance that begins and structures the first allto and the text as a whole - a discursive performance, that is, within a textual tradition: Calisto's address to Melibea is a pathetic deployment of the Ars amoris of Andreas Capellanus (Deyermond, "Textbook;" Hall Martin, Love's Fools, Gaylord 5). This weaving of textual traditions and texts into discourse begins the process of the novel as speakers use inventio and dispositio to select and bind together texts and arguments from which they generate and fashion their own texts.

Calisto and Celestina are the primary generators of texts; theirs are the ones to which all other characters must respond, against which they must guard, and which they both critique and attempt to deploy for their own advantage throughout. Even Celestina carefully adjusts in auto IV to the discourse of doncella brava generated by Melibea along with the textual tradition of moral reprehension, until she manages to draw Melibea into the equivocal metaphor of healing Calisto's pain (IV.33 ff., Severin $164 \mathrm{ff}$.) and thereby into its literal reference, the love-story she (Celestina) and Calisto are piecing together.

The characters of Celestina dismember, splice, and penetrate each other's texts and discourses in interaction with one another, rhetorically 
pitching their discourses according to the needs of the moment (Gilman, Art 43 ff.). Calisto and Celestina do so with the intention of seducing others. With Melibea and Pármeno, the two to whom these words are most often directed, they often oppose the will (and the texts) of their interlocutors, using the same strategy of discursive and textual splicing for desires and goals of their own.

In Celestina, these texts, driven and formed by carnal appetites, work both to keep the action within the realm of controlled discourse, ${ }^{17}$ and to move beyond words to exert their will over the world of actions and of things (persons, bodies, and cash are all equally textualized and objectified) ${ }^{18}$ This thrust-and-parry of discourse and action is especially patent in Celestina's soliloquy en route to Pleberio's house to make contact with Melibea on Calisto's behalf. It is the threat of Calisto's reaction should her accomplishment not be correlated to her word, along with her reading of several agileros, that give her the stimulus to carry through (IV.1 ff., Severin 149-51).

Yet, in the end, Calisto's and Celestina's words don't succeed in controlling wills and actions amidst the "lid y ofensión"; the direct resistance in the encounters of texts and discourses, as well as the indirect resistance latent in the asides, show the points at which the sutures holding together disparate stories and sententine will come undone. When Celestina in auto XII ignores or refuses to accept Sempronio and Parmeno's as the bravos of their fiction and tries to impose her own, her body and discourse, like her house "medio caída, poco compuesta y menos abastada" (I.94, Severin 110), are imploded by the jabs of their swords. This excessive force, however, is a violence already latent in the asides in which they have criticized her (e.g. V.12, Severin 173-174 et passim), in their roles as thugs, and in their moral discourse about "viejas avarientas" (V.12-.13, Severin 173-174 et passim; culminating at XII.100, Severin $271 \mathrm{ff}$.).

17 As Celestina tells Pármeno: "El deleite es con los amigos en las cosas sensüales; y especial, en recontar las cosas de amores y comunicarlas (...) Este es el deleite, que lo ál, mejor lo hazen los asnos en el prado" (I.161-.162, Severin 126).

18 The term 'voluntad' is an extraordinarily important one in Celcstina and occurs with great frequency in the text. See Lloyd Kasten and Jean Anderson, Concordance to the $<<$ Celestina $>$ (Madison, WI: Hispanic Seminary of Medieval Studies and Hispanic Society of America, 1976). 
When Calisto in auto XIX must assume the active role of the galán which he has played discursively, he misses his step, and his fallen courtly text explodes, scattering his brains like so many scraps before the toroellino of text and textuality set in violent motion by his appetite. Not only pleasure or gain, but violence is invoked by means of the sensitive deployment of texts and discourses and the all-too-critical readings of them, a dynamic that can be seen throughout Celestina.

The discursive sensitivity that animates the texts and the violent resistance to them are latent in the beginning of the "processo del deleite destos amantes" (P.26, Severin 81), as for example, in Melibea's answer to Calisto's opening text, a vehement reprehension of his breach of courtly codes and a harsh commentary on his mis-handling with the text of courtly love (Deyermond, "Textbook"). She responds to his transgression as a discursive one: "Véte, véte de aí, torpe: que no puede mi paciencia tolerar que aya subido en coraçón umano error de comigo el ilícito amor comunicar su deleite" (I.7, Severin 87; emphasis mine). Later, she shows her own superior mastery of the rules of the courtly discursive form and reveals a critical sensitivity to Calisto's performance when discussing him with Celestina ("haciendo mucho del galán;" IV.65, Severin 163), and characterizes his rhetorical error as "desvariaar comigo en razones" (IV.65, Severin 163; cf. Read 89). Their dialectic of seduction and resistance begins in self-conscious discursive performance; it is then mediated through Celestina as a tongue inscribed with "razones" (XII.29, Severin 261), and is given shape throughout by varied discursive and textual traditions.

Indeed, both before and after the seduction, Melibea and Calisto assume various discursive roles formed from the literary (and social) texts of the late 15th and early 16th centuries, especially courtly ones, parodied for the most part in the lovers' discursive actions - ill-suited poetry and song, extremes of cancionero/Petrarchan love-language, the formality of their interviews punctuated by Melibea's protests of Calisto's rough advances. ${ }^{19}$ Throughout the "processo de su deleite destos

${ }^{19}$ For discussions of Celestina's characters, especially Calisto and Melibea, as courtly figures who also quote courtly texts see, among others, Devlin and Hall Martin on Celestina as a parody of courtliness, Deyermond's "The Textbook Mishandled," Lacarra on the relationship of Celcstina to the sentimental novel, and Kassier's analysis of how Celestina literalizes courtly metaphor. Deyermond's Petrarchan Sources, Castro Guisasola, and Lida de Malkiel are the standard treatments of Cclcstina's sources, and the latter two document the many citations from courtly works in the mouths of these characters. 
amantes," all of these discursive and textual aspects of their interactions are commented on as performances by those listening (Read 87-9).

Throughout Celestina, the characters monitor discursive performances and very consciously adopt different levels of decorum to suit both the context and particular goals; they shape, respond to, and critique the dialogues in which they take part or which they overhear. ${ }^{20}$ The first act again offers good examples; Sempronio's presentation of the plan to fleece Calisto is rigorously formal - note his attempt to capture Celestina's benevolence by suggesting his own loyalty to her: "[Y] quiero que sepas de mí lo que no as oído; y es que jamás pude, después que mi fe contigo puse, dessear bien de que no te cupiesse parte" (I.83, Severin 107).

This formality is not lost on Celestina; her response, however, is to locate their discourse on another level, that of "amistad," where there is no need for such formality - "preámbulos ni correlarios ni aparejos para ganar voluntad" (I.84, Severin 107) - and where few words well spoken suffice. Celestina's reply is equally formal and a critique of Sempronio's rhetorical performance, telling him to get to the point. But it doesn't necessarily indicate credence of Sempronio's motives on her part, since, as we soon hear in her aside to Sempronio criticizing Calisto, "que de las obras dudo, cuánto más de las palabras" (I.122, Severin 116). Celestina's rhetorical sensitivity to register and discourse is clearly operative; these are old bones she's gnawed and knows well (I.122, Severin 116), until she is blinded by greed in XI and loses control of her own text as well as "reading" Sempronio and Pármeno badly. ${ }^{21}$

All characters of the lower class - Pármeno, Sempronio, Celestina, Areúsa, Lucrecia - critique discourses of their señores; many critique Celestina as well, often sarcastically (cf. n7). Beginning with Sempronio, there is constant reproach of Calisto, often of his discursive habits and often, although not always, offered in asides (throughout I, cf. especially VI.52 ff., Severin $187 \mathrm{ff}$., and VIII.44 ff., Severin 221). The critique of Celestina by Sempronio and Pármeno is both unrelenting and

${ }^{20}$ Read, 87 , comments on the formality and rigidity of the discourses taken up by the characters, without taking into consideration the discursive texture that I point out here.

${ }^{21}$ This sensitivity is also evident in the above mentioned aside (I.122, Severin 116), as well as in her discussions with Pármeno (I.125 ff., Severin $117 \mathrm{ff}$. and VII.1 ff., Severin $192 \mathrm{ff}$.) and Meliben (autos IV and X). 
violent (especially Pármeno in VI). Nor is Melibea exempt from discursive criticism or threat from Celestina (in asides) in their encounters of IV and X (Celestina to the cordón: "yo te haré traer por fuerça, si bivo. .." in .her soliloquy at V.5, Severin 172). ${ }^{22}$ Too, Melibea comments on Celestina's rhetoric in IV, for her brazen mention of Calisto (IV.59 ff., Severin $161 \mathrm{ff}$.) and for beating around the bush: "Si esso querias, ¿por qué luego no me lo expressaste? ¿Por qué no me lo dixiste por tales palabras?" (IV.70, Severin 164).

To this, Celestina responds with her usual sophistication, citing first her "limpio motivo" and then the fact that "la verdad no es necessario adumbrar de muchas colores" (IV.71, Severin 164). Melibea, however, continues her critique of Celestina in discourse: of what people say about Celestina as well as about what Celestina says, of the ironic public "loores" of Celestina's "falsas mañas" and of Celestina's inability to tell the truth (IV.75-6, Severin 166). ${ }^{23}$ To counter Melibea's discursive resistance, Celestina, upon leaving after the first interview, promises to subject Melibea to a fittingly discursive punishment: "¡Ay, cordón, cordón, yo te haré traer por fuerça, si bivo, a la que no quiso darme su buena habla de grado" (V.5, Severin 172; emphasis mine; also IV.88, Severin 169). In her second encounter with Melibea, Celestina gloats "tú me pagarás, doña loca, la sobra de tu ira" (X.8, Severin 239), and proceeds first to withhold and then to batter Melibea with Calisto's name (X.9-.36; Severin 239-245). When Celestina has seduced Melibea in $X$, her punishing words work on Melibea's body not to heal (as medicine or suture, "congrua e saludable melezina" or punta), but viciously to prolong Melibea's agony, punctuating it with Calisto's name. In the end Melibea totally succumbs to Celestina's discourse, physically collapsing as her discursive resistance is broken, along with her "onestidad" and

${ }^{22}$ She and Calisto, as well as Sosia and Tristán are criticized discursively by Lucrecia as well, although more from Lucrecia's own appetite being whetted by overhenring Calisto and Meliben making love (XIX.23-4, Severin 324). This is, however, an interior aside (Lida 136).

${ }^{23}$ Celestina is perfectly capable of being accurate, but seldom in order to communicate the truth, as in her final and fatal interaction with Parmeno and Sempronio, in which she probably is accurate about her own opinion of her worth and salary, although not necessarily to communicate the truth about the chain, since she's previously created other fictions to put them off (XII.77 ff., Severin $270 \mathrm{ff}$ ). 
"empacho" (X.7-.47, esp. .39, Severin 239 ff.). ${ }^{24}$ The interweaving of the moral discourse of doncella brava and the surgical discourse of healing, then, opens rather than heals her secret wounds.

The discursive inter/actions of characters in Celestina are textually framed and evaluated, and lead to other kinds of actions framed and moved by words, which, in the chain of events of Celestina, show all discourse to be less melezina, than to be "polvos de infamia" and "licor de corrución" (X.21, Severin 241; compare with I.163, Severin 126). In the rhetorical and discursive joining of texts, such tactics work not to heal but to destroy, unable to contain the violence conjured by their combining.

Entre tus manos, hecho pedaços (X.11): Broken Stitches and the Death of Discourse

As we have seen, Celestina and Calisto die in the throes of an inefficacious discourse/performance. No matter how well Celestina deploys her discursive arts in IV and X with Melibea (the former says as much in her commentary on Celestina's text from IV at X.42, Severin 2456), in XII she chooses badly the texts she deploys with Sempronio and Pármeno, splicing badly a series of possible stories and explanations pot-boiler logic - that cancel each other out (XII.79 ff., Severin $270 \mathrm{ff}$.). Calisto, never an apt player in the game of discourse and textuality, stumbles while in full performance of the galán for Melibea and for their servants. Both Calisto and Celestina are obviously commented on throughout the town in life and in death, as we hear from the remaining characters.

The most bitter outcomes of discourse, however, are contained in Melibea's and Pleberio's performances. At the moment of her suicide in XX, Melibea creates a text without the possibility of dialogic response, although once again with an eye to the audience, whether her father as (silenced) interlocutor, Lucrecia as invisible on-looker, or her mother or community as implicit witnesses. Pleberio's need to know the end of Melibea's story allows her to coerce him into passivity until she cashes in her body ("pon tú en cobro este cuerpo que allá baja," XX.31, Severin

24 See Otis Handy, "The Rhetorical Defloration of Meliben," Celestinesca 7.1 (mayo 1983): 17-27. Handy's reading of $X$ as both erotic and crucial to our understanding of Meliben's seduction is quite to the point. 
$335)^{25}$ and closes her text by flinging herself from her tower (XX.12, .18 ff., Severin $331 \mathrm{ff}$.). She rejects the power of words to change her course of action or of books to console her, and confesses to a lack of coherence in her own discourse (XX.20, .30, Severin 333-5).

Yet Melibea's final words are well within the textual and discursive tradition of confession or apologia, and she attempts to justify her actions, and to frame her story adequately if not accurately. ${ }^{26} \mathrm{Her}$ final fall is meant to control the text from beyond the grave: "No digan por mí: a muertos y a idos, pocos amigos" (XX.29, Severin 334). So that she may reenter Calisto's text, she implores her father to finish their story in death by burying them together, united in the final words of joint ceremonies as well as in adjoining graves - "juntas nuestras sepulturas, juntas (...) nuestras obsequias" (XX.29, Severin 334).

Her death will close the story, silencing future dialogue; her father watches from the foot of her tower, now on the margin, forbidden to respond. While Pleberio's tears speak to her, like those "consolatorias palabras" which she cannot recall from the "antiguos libros," we never know what they say to her, and her final discursive farewell to her "vieja madre" and to Pleberio fall into the void with her. As George Shipley

25 Both in Covarrubias and the Diccionario de la lengua española, 'cobro' is related clearly to 'cobrar.' In the former, we have for cobrar "recebir la paga de lo que se deve (...) Cobro, vale recaudo. Poner una cosa en cobro, alçarla donde no la hallen. Algunas vezes sinifica gastarla, venderla y consumirla" (382). Too, the Diccionario cites two archaic meanings for the word 'cobro:" "lugar donde se asegura, guarda o salva una cosa" and "expediente, arbitrio, providencia, medio para conseguir un fin" (DLE I:328). It goes on to define 'poner in cobro' as "colocarla en paraje donde esté segura" (DLE I:328). I am using the terms 'cashing in' and 'banking' to refer to Meliben's own articulation of her body in death because of the semiotic overlap of collecting debts, banking currency, and safeguarding a valuable object; in addition, as the last definition in Covarrubias indicates, she may well be referring to being consumed or wasted by death. Here, Melibea's body is all of that, as she well knows, because of being the heir of her father's estates as well as a beloved object consigned to the sifety of the tomb. In this regard, Melibea speaks not "naturally in a language of her own" (Dunn 416) but in the language of commerce which Dunn analyzes so well in "Pleberio's World" and as such is not exempt from or innocent of but rather cognizant of and complicit with the values Dunn attributes to Pleberio.

${ }^{26}$ Melibea's account of the month of love she and Calisto had spent (XX.26, Severin 334), along with other apparent inconsistencies of time in Celcstina has provoked a good bit of scholarly inquiry; in addition, her account of the effect of Calisto's death may well be more than a little exaggerated. 
notes, Melibea's discursive position calls into question the possibility of any textual authority just as the impossibility of dialogue is "punctuated forcefully by her final act" (Shipley 104).

Ultimately, Pleberio goes from her monologue to one of his own, and, in it, from apostrophe to apostrophe, figuring his own sorrow by means of an imagined moment of frustrated desire for dialogue in her empty room: "¿Qué haré de que no me respondas si te llamo?" (XXI.22, Severin 340). In his anguished planctus Pleberio chides the World and Love not just for their actions but for their unintelligible and manifestly false discourses; "prometes mucho, nada no cumples," he accuses "mundo falso" (XXI.15, Severin 339). ${ }^{27}$ Like Melibea, he does not find any commensurate text in which to find solace, even though he too searches his memory for appropriate examples from the textual tradition they share. Pleberio, like Melibea, leaves off the search for adequate textual correspondence in his apostrophic complaint addressed to the World or to Love, "Otros muchos que callo, porque tengo harto que contar en mi mal" (XXI.32, Severin 343). Between counting the broken body Melibea has banked with him (XX.31, Severin 335) and recounting the broken history of her fall (filled out by Lucrecia), Pleberio falls silent in a vale of tears, faced with and generating an irremediably torn text, with neither melezina nor puntas to heal the wounds.

Engendrar en su cuerpo quien coma sus entrañas (P.13): Margin, Dialogue, and the Form of the Book

I recount the story-line of Celestina to show how the novel's fissured textuality calls attention to its own entanglements with books, texts, and discourses; rather than discourse analysis, a cynical and specular philosophy of language and textuality in human intercourse is called for in Celestina. As we have seen in Rojas' scene of reading, this aspect of the text is laid out soberly in the Prologue, and is violently foregrounded in the final monologues of Melibea and Pleberio. Here,

${ }^{27}$ Dunn develops a critique of Pleberio in which he analyzes how the basic images and values of Celestima are commercial and materialistic; Gaylord further develops Dunn's basic idea of the materialism inherent in the text in terms of the world as a feria in which the main commerce in of language. I follow Dunn in seeing the commerce of the text as being a negative and destructive force which Celestina critiques; however, I agree with Gaylord that the commerce is one of discourse, and that the traffic in language is one of the principal themes of the text. 
then, is the end to which the text and all discourse have progressed in Celestina - they are ultimately rendered impossible by loss and excess.

As Cervantes would do later in the Quijote, Rojas makes readers and reading, texts and textuality integral to Celestina as each character comments on the texts of his or her $\operatorname{com}(\mathrm{p})$ adres in order to castigar. Each situates him or herself within shared rhetorical and textual traditions. Textual interplay in the asides, as we have noted, is both punishment and healing for the problematic textuality of Celestina; as such, the asides are metaphorically index and gloss, the margin integrated into the text itself, pointing out - as well as responding to an utterance or locution in order critically to supplement the main focus of the scene.

If we consider critical asides as glosses, however, we find that they do not simply supplement, but that they subvert, pointing like a maniculum drawn in the margin to the fissures in the text. ${ }^{2 \mathrm{~B}}$ They often cut through the illusions many characters, especially Calisto and Celestina, weave about themselves as they adopt personae in interaction with others, personae that eventually generate a violence that engulfs them. Rojas et al provide this counterpoint of text and gloss, a counterpoint that he knew well and employed in his glosses of Petrarch and of his readers in the Prologue. ${ }^{29}$

As is clear in the Prologue and the acrostic verses that preface his text, Rojas found his own words to be perilous, exposing him as they did to the "qué dirán" of his day. That peril in fact materialized in the conflict generated by the Comedia, and a text which in turn, devoured by its own offspring 'con lid y ofensión de lectores,' generated from itself the Tragicomedia, just as Rojas had himself devoured his predecessor's

28 Louise Fothergill-Payne explores the subversive uses of citations from Seneca in "La cita subversiva en Colcstina"; however, I am signalling the ways that Celestina internally subverts its own discourse by the ways that discourse is represented in the text.

${ }^{2}$ Apropos the interpolation of the Tragicomedia at V.10-.11, Gilman notes that Rojas supplies "a clarifying glosa to explain the hidden significance" of the text (Art 32). 
text. $^{30}$ Rojas' imaging of the reading of his text in the Prologue (P.19 ff., Severin 80-1) is a scene of interpretation, mostly inept, entirely conflictive, but extremely fecund, producing not only a generically hybrid title but also a drastic amplification of the text, one which has not ceased to trouble editors and scholars ever since.

As we can see in Rojas' portrayal of readers' importunate demands for more of the love story, the reading of the Comedia by his contemporaries thoroughly undercuts his "limpio motivo" of making a moral and reprehensive text (OA.4, Severin 72-73). It would seem that his own sutured text seduces rather than warns for the most part, since the majority of his readers emphasize the "processo del deleite destos amantes" and not the moralizing reprehension of the madness of love and the falseness of servants, nor the saturation of intertextuality and the disintegration of discourse which Rojas emphasizes time and again. Rojas does accede to extend the affair of Calisto and Melibea, "aunque contra [su] voluntad" (P.26, Severin 81), and his indirect negative exemplarity, consigned to his own indices in the prefatory materials and concluding verses, remains a gloss to his own text unheeded by many of his contemporaries. Indeed, it has proved problematic as well for scholarly readers intent on making the text one and whole.

Because of this self-conscious representation of the complexities of both textuality and of reading, both Hans Ulrich Gumbrecht and Roger Chartier have chosen to discuss Celestina as a key text in the history of reading and textuality. In "The Body vs. the Printing Press ...," Gumbrecht takes Celestina to be emblematic of the effects of the shift from manuscript to print culture, using the text to figure a radical rupture from manuscript to printed text. At the metadiscursive level, however, Celestina marks not simply the erasure of the body, but also its undeniable presence as well as its violence and fragility. Nor does the printed text escape the effects of the body either in terms of making or interpreting it, as Rojas' printers point out, and his readers exemplify in the way that their ages condition their struggles with the text (P.21, Severin 80).

${ }^{30}$ See Charles Faulhaber's transcription of the Palacio ms. of part of the first act, as well as his comments on what this might indicate of Rojas' textual practices. It is of note the extent to which Rojas may be said to have revised the ms. of the first auto, as well as the extent to which the coexistence of manuscripts and printed texts is indicated. 
This early printed text bridges both the incunabulum and the early modern periods of printing and, I would suggest, figures the body of the book by the bodies within its text. Like them, it is in crisis, with meaning residing neither in the world nor in consciousness whether corporal or textual, as Hans Ulrich Gumbrecht observes ("The Body" 187). The medieval manuscript is considered to be more corporal - produced and often glossed and commented by hand - adding to its margins meanings assumed to reside in its text. Yet this is also the form of the early printed book, which maintains a close resemblance to the manuscript book in format (which often included printed as well as written marginal commentary). Indeed, the latter likewise requires intense labor to produce, as did the manuscript book; early hand presses required several men in close work, and also included hand rubrication and illumination of the text. The early printed book is associated by Gumbrecht with a more 'textual' mode of consciousness generated by the printing press, as the primary mode of book production, in direct conflict with the personal consciousness associated with the hand-produced book (185-187); but the overlap is perhaps better characterized as a moment of transition, since incunabula and Early Modern books seem to participate in similar kinds of production and consciousness. ${ }^{31}$ Indeed, Celestina can be seen to reflect a textual world in transition, one in which both types of text are fissured by the strain of that transition. Caught between the Middle Ages and the Renaissance as shaped (and conceptualized) around the form of the book, the discursive and textual world of Celestina is caught up in the powerful play of the word - uttered, commented, repeated, accessible - circulating far beyond what had theretofore been imaginable, and helping to create in Spain a complex and critical intertext.

Chartier takes Celestina as exemplary of the complexity of the historical practice of reading, and glosses a fragment of Rojas' text - the scenes of reading in the Carta and the Prologue - to show how a new history of the book and of reading practices, bridging the alleged abyss between the oral and the written, might be articulated. He comments on Rojas' first two kinds of readers as butchers who "mutilate the work and miss its true meaning" - the ones who make the text a "cuento de

${ }^{31}$ See in particular the essays collected in Printing the Written Word: The Social History of Books, circa 1450-1520, ed. Sandra L. Hindman, especially the introduction and the essays by Sheila Edmunds ("From Schoeffer to Vérard: Concerning the Scribes Who Became Printers," 21-40) and Paul Saenger and Michael Heinlen ("Incunable Description and Its Implication for the Analysis of Fifteenth-Century Reading Habits," 225-258). 
camino" and those who take out bits and pieces - contrasting them with those who "put into operation a plural reading (...) whose 'first person' is applicable to everyone" (Chartier 155). Chartier seems to be a somewhat surgical reader, predicted and figured by the text.

Chartier is right, however, in taking Celestina to be paradigmatic of the nature of the book and its readers in a complex world of words, texts, and readings. In proposing a new, more nuanced history of books and readings, Chartier calls for "an inventory of the multiple divisions that fragment the social body" rather than the "macroscopic opposition between 'popular' and 'high' culture" "which often defines the common people by default as the collection of those outside elite society" (169), and whose relationship to the printed word, we might say, has long been considered an aside in its history.

Perhaps more than Chartier thought, Celestina figures the critical interaction of a complex and divided world of words and power. Within this text, the conflicts are particularly lisible in the person of Celestina herself, who is after all the space in which words and desires take on flesh in the form of action (cf. IV, scene 1, already commented above on p. 00). Her tongue is the textual support of the message that Melibea sends Calisto, and must stand in for action at their first meeting:

Pero, pues no se puede al presente más hazer, toma la firma y sello de las razones que te embië escritns en ln lengua de aquella solícita mensajera. Todo lo que te dixo confirmo (...). (XII.29, Severin 261)

Melibea's voice (body and testimony) confirm the text, but the effect of Celestina's scarred textual body as corrupt and corrupting material support of their communication is clear in the (potentially senseless) discursive and physical-violence that follow.

Calisto and Melibea displace the focus onto the scene of idyllic love, which, in a world of textual and discursive violence and risk, can hardly be imagined to be utopic, no matter how much Calisto wants to make it a spectacle of divine love. ${ }^{32}$ Celestina embodies textuality in the novel, meretricious and scarred as she is by violence, inviting us to read her in a way that pleases us enough to do and see what she wants. The

${ }^{32}$ I am thinking especially here of Calisto's exhibitionism, e.g. XIV.14, when Melibea sends Lucrecia away, and Calisto protests: "¿Por qué, mi señora? Bien me huelgo que estén semejantes testigos de mi gloria" (Severin 285). 
asides, like Celestina's scars, always direct our attention away from courtly love to the circulation and debasement of courtly texts, to the conversation, not necessarily noble, of texts, discourses, and appetites.

As readers 'provocados a lujuria textual,' we are drawn by our textual desires into Celestina - or resist the temptation, whether by lid or litigio. ${ }^{33}$ The words of the text work in and through our own bodies, whether through delighting us by the desire of Calisto and Melibea for each other, or reforming us through its warnings about love and deceit. But the text, like Celestina herself, leaves us no certainty of any moral. This is so, in part, of course, because of the further fragmenting of discourse by the running commentary that accompanies it.

After centuries of readerly conflict, our own punturas, like those of the printers (P.24, Severin 81), help us to make sense of the text. To make the text readable, modern editions include additional textual supplements like the word "aparte" in parentheses for the asides, critical apparatuses to explain the state of the text(s), extensive notes to "aclarar todos los problemas textuales e histórico-literarios o histórico-lingüísticos" (Russell 14), signalling additions and deletions. Yet editions create a pastiche text, neither Comedin nor exactly Tragicomedia, by leaving the deletions made to the Comedia to produce the Tragicomedia while incorporating all the interpolations and added text.

Each edition is a reading, an attempt to reveal Celestina's truth(s), to fill out and fix its lexical and textual references, often diverting our engagement from the philosophical and ethical issues pointed to in the prologue. $^{34}$ Gilman's work, brilliant and necessary as it is, argues the unity and "authenticity" of a living text, all the while working with that text on the basis of its radical textual and dialogic instability: its radical textuality. Like Gilman, as readers and critics, we add our own commentary to the text, perhaps a not-so-implicit violence on our own part, perhaps surgical like that of the dialectician in Plato's Phaedrus, who cuts at the joints to get at the truth of things by analytical division

${ }^{33}$ Covarrubias relates the two terms etymologically in his Tesoro de la lengua castellana o española (1611), facs. Madrid: Ed. Turner, 1977.

${ }^{34}$ See Jerome McGann, The Tcxtual Condition, for the interpretive nature of textual editing. The introduction to P. E. Russell's recent edition of Cclcstiva is particularly revenling in its attempts to make Celcstina a stable and transparently lisible text. 
(Plato 265E-266A, 534-535) and then sews them back together in the comely body of his own rhetorical performance.

But Celestina's punturas can't restore Melibea's virginity or put her back together again. Nor can Celestina restore herself to wholeness once dismembered, any more than Socrates' dialectician can take the textuality and violence out of the voice, or the voice and violence out of the text. As I hope to have shown, the asides make visible the chaotic plurality of Celestina's text, a chaotic plurality ranging from the multiple and conflictive sites of discourse, to the plural and conflictive intertext mobilized in its pages, both culminating, first, in fragmented monologue, and then in ultimate silence. We are left in the readerly position of Pleberio, drawn into the text and facing vital but problematic, fragmented and deeply textual voices from and about which we try to make intellectual and moral sense, as we perform celestinesque operations on it with our own pens and punturas.

\section{WORKS CITED}

Azar, Inés. "Speech Act Theory on Self, Responsibility, and Discourse." Homenaje a Ana María Barrenechea. Ed. Isaías Lerner and Lía Schwartz Lerner. Madrid: Castalia, 1984. 33-40.

Bataillon, Marcel. La Célestine selon Fernando de Rojas. Paris: Marcel Didier, 1960.

Beinart, Haim. Records of the Trials of the Spanish Inquisition in Ciudad Real. Jerusalem: Israel National Academy of Sciences and Humanities, 1974.

Castro Guisasola, F. Observaciones sobre las fuentes literarias de la Celestina. Anejo 5 of Revista de Filología Espaniola, 1924. Rpt. Madrid: CSIC, 1973.

Cervantes, Miguel de. Don Quijote de la Mancha. 9th ed. Ed. Martín de Riquer. Barcelona: Juventud, 1979; orig. pub. 1944.

Chartier, Roger. "Texts, Printings, Readings." In The New Cultural History. Ed. Lynn Hunt. Berkeley: U California P, 1989. 154-175.

Covarrubias, Sebastián de. Tesoro de In lengua castellana o española. 1611. Facs. Madrid: Ed. Turner, 1977.

Devlin, John. "The Celestina": A Parody of Courtly Love. Madrid: L.A. Publishing Co., 1971. 
Deyermond, A. D. The Petrarchan Sources of 'La Celestina'. Rept.with new preface and supplementary bibliography. Westport, Conn: Greenwood Press, 1975; London: Oxford UP, 1961.

"The Textbook Mishandled: Andreas Capellanus and the Opening Scene of Celestina." Neophilologus 45 (1961): 218-221.

Dunn, Peter N. "Pleberio's World." PMLA 91 (1976):406-419.

Faulhaber, Charles. "Celestina de Palacio: Rojas' Holograph MS." Celestinesca 15.1 (mayo 1991): 3-52.

Finch, Patricia. "The Uses of the Aside in Celestina." Celestinesca 6.2 (noviembre 1982): 19-24.

Gaylord, Mary Malcolm. "Fair of the World, Fair of the Word: The commerce of Language in La Celestina." Revista de Estudios Hispánicos 25 (1991): 1-27.

Gilman, Stephen. The Art of 'La Celestina'. Madison: U Wisconsin P, 1959. The Spain of Fernando de Rojas. Princeton: Princeton UP, 1972.

Gumbrecht, Hans Ulrich. "The Body vs. The Printing Press: Media in the Early Modern Period, Mentalities in the Reign of Castile, and Another History of Literary Forms." Sociocriticisin 1 (1985): 179 202.

Hall Martin, June. Love's Fools: Aucassin, Troilus, Calisto and the Parody of the Courtly Lover. London: Tamesis, 1972.

Handy, Otis. "The Rhetorical Defloration of Melibea.' Celestinesca 7.1 (mayo 1983): 17-27.

Hindman, Sandra L. Printing the Written Word: The Social History of Books, circa 1450-1520. Ithaca: Cornell UP, 1991.

Kassier, Theodore L. "Cancionero Poetry and the Celestina: From Metaphor to Reality." Hispanófila 56 (1976): 1-28.

Kasten, Lloyd and Jean Anderson. Concordance to the $<<$ Cclestina $>$. Madison, WI: Hispanic Seminary of Medieval Studies and Hispanic Society of America, 1976.

Lacarra, Maria Eugenia. "La parodia de la ficción sentimental en la 'Celestina'." Celestinesca 13.1 (mayo 1989): 11-29.

Lapesa, Rafael. "En torno a un monólogo de Calisto." In El Comentnrio de texto. 3d ed. Ed. Andrés Amorós. Madrid: Castalia, 1973.

Lida de Malkiel, María Rosa. La originalidad artística de 'La Celestina'. 2nd ed. Buenos Aires: EUDEBA, 1970.

McGann, Jerome. The Textual Condition. Princeton: Princeton UP, 1991.

Morón Arroyo, Ciriaco. "Sobre el diálogo y sus funciones literarias." Hispanic Review 41 (1973): 275-284.

Moudoud, Chantal Cassan. "El Uso de los apartes en Celestina." Celestinesca 11.2 (noviembre 1987): 13-20.

Plato. Phaedrus. In Plato I. The Loeb Classical Library. Trans. H. N. Fowler. Cambridge, MA: Harvard UP; London: Heinemann, 1914, repr. 1982. 
Read, M. K. "The Rhetoric of Social Encounter: La Celestina and the Renaissance Philosophy of Language." The Birth and Denth of Language. Madrid: Porrúa, 1983. 70-96.

Real Academia Española, Diccionario de la lengua espanfola, 20th ed. Madrid: Real Academia Española, 1984.

Rojas, Fernando de. Celestina. Tragicomedia de Calisto y Meliben. Ed. Miguel Marciales. Prepared by Brian Dutton and Joseph Snow. Urbana and Chicago: U Illinois P, 1985.

- Comedia de Calisto y Melibea. Burgos, 1499. Facs. New York: Hispanic Society of America, 1909; repr. 1970.

- La Celestina. Ed. Dorothy S. Severin. Madrid: Cátedra, 1987.

Russell, Peter E. Introduction. Comedia o Tragicomedia de Calisto y Melibea. By Fernando de Rojas. Ed. P. E. Russell. Madrid: Castalia, 1991.

Severin, Dorothy. "Humour in La Celestinn." Romance Philology 32 (19781979): 274-291.

Shipley, George. "Authority and Experience in La Celestina." Bulletin of Hispanic Studies (Liverpool) 52 (1985): 95-111.

Simpson, Leslie Byrd. Preface. The Celestina. A Novel in Dinlogue. By Fernando de Rojas. Trans. Leslie Byrd Simpson. Berkeley: U California P, 1955.

Strodt-Lopez, Barbara. "Tying it all in: Asides in university lectures." Applied Linguistics 12.2 (1991): 117-140.

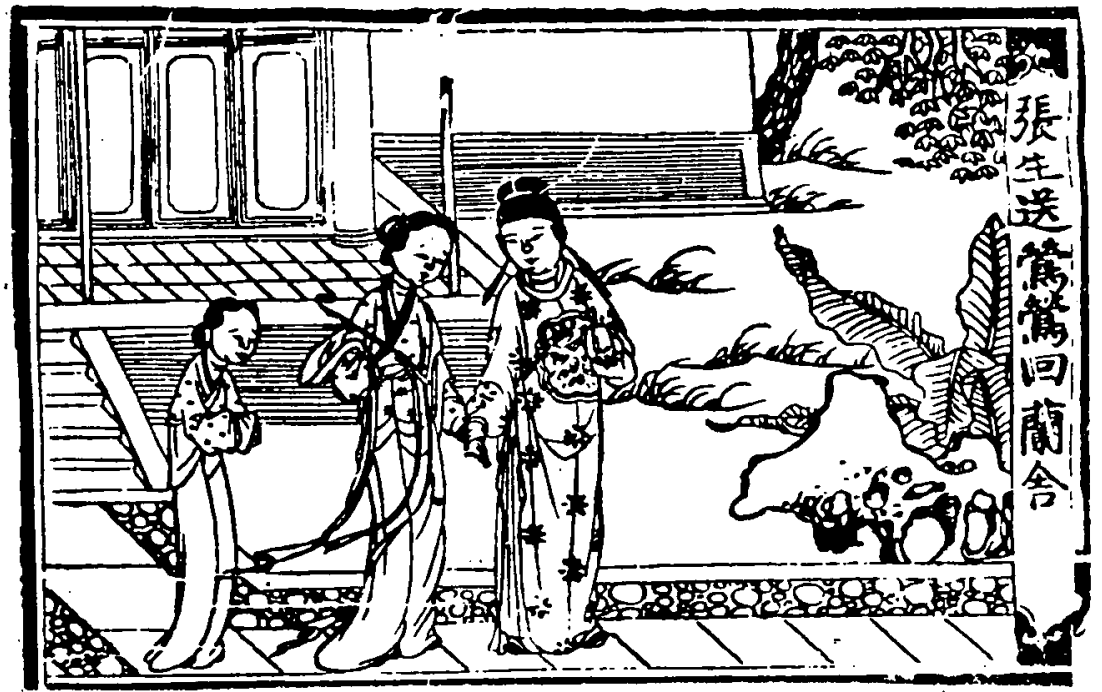

Woodcut from Wang Shi-fu, Relato del Pabellón Occidental. (see p. 183, no. 819) 